\title{
Singing and dancing in the cruellest month:

\author{
A reflection on theology and poetry \\ in a time of COVID
}

\section{Christopher Southgate}

Christopher Southgate is Professor of Christian Theodicy at the University of Exeter and is the author of eight collections of poetry.

This essay considers what contribution the arts can make to the human experience in a time of pandemic, with particular reference to works of art informed by the Christian vision, broadly understood. In the extraordinary and powerful dialogue Proverbs of Ashes, in which Rita Nakashima Brock and Rebecca Ann Parker tell of their experience of violence and abuse, and of what kind of theology will and will not meet such experiences, Parker writes this:

I did not defeat negative feelings of anguish and despair because I saw something more lovely and good. Rather I became able to feel more. My feeling broadened. Pain, sadness and despair were not eliminated or overcome. I embraced them with a larger heart. ${ }^{1}$

That beautifully describes what I see as the contribution of the arts to the current COVID crisis. No poem, painting, sculpture or sonata, however lovely and good, will eliminate the huge experience of loss that so many have experienced in such a range of ways - from the actual loss of relatives who joined care home statistics, without ever having the chance to hold for a last time the hand of someone they loved, to the huge loss of opportunities this time represents. So evidently for those in formal education, and graduates looking for first jobs, but at every stage of careers and life-journeys there are losses of possibility that are hard to process, let 


\section{Singing and dancing in the cruellest month}

alone overcome. And no dance or drum solo can dissipate altogether our fear, the underlying anxiety of the time. But the best, the most excellent, of artistic productions can, I believe, enlarge the heart, in a way that fits us better to embrace the uncertainty and tragedy of this epidemic, and find within it also ingredients of future wisdom and hope, ingredients that may go beyond what could have been thought before. What has happened has happened. It is not defeated by appeal to art. But perhaps it may be woven, with the aid of the finest of what the human spirit and ingenuity can contrive, into a larger imaginative story.

And that, I suggest, has been the characteristic response of the people of God (as recounted in the Hebrew Bible) to disasters, as we see in particular in the response of the Israelites to successive defeats, and ultimately exile in Babylon. New songs were sung in the strange land, laments of extraordinary ferocity, pathos and power. But also new cosmologies were devised that helped the people embrace their situation and reframe it within a larger story. That may be an unfamiliar way to read the first chapter of the Bible, as a response forged in the crucible of defeat, disaster, loss of all stability, and horrendous uncertainty about the future, but I invite you, next time you read it, to consider it as a way to encourage the people of God into an enlargement of the heart.

My chosen artform to discuss in this essay is poetry, and I shall use three poems to illustrate my thesis. The first was published in 1922, formed out of the experience of the horrendous loss of life not only in the First World War but in the Spanish flu epidemic. The second was published in 2001 but refers back to the Irish famine of 1847. The third was written for Easter 2020, in the first intensity of the COVID crisis.

My mother once said to me, 'I wonder how poetry works.' And of course we can come up with easy answers, that the devices of poetry, especially rhyme and assonance, rhythm and cadence, take words into the human spirit via our neurophysiology. I am irresistibly reminded of that scene in the film Dead Poets Society when the teacher explains iambic metre simply by having the class walk together round a courtyard. And once, on what seems a day from a whole world away, on the road to Compostela, I taught a teenager pentameter in a square at sunset, simply by pointing out that he had just been speaking in it. Rhythm is deep in our bodies, in our heartbeat, in our circadian patterns. Rhythm, and broken rhythm, and our 


\section{Singing and dancing in the cruellest month}

visceral reaction to the music of words, lies behind our deep and largely unconscious response to the speech and gestures of others.

Perhaps these reflexes are vitiated by the bombardment of stimuli in our present urban and digital environments. We do not sit easily through day-long declamations of oral poetry; we do not, as the ancient Athenians did, consume three Greek tragedies at a sitting. It is hard to concentrate through the longer Shakespeare plays at the Globe, even if the helicopters are going the other way that day. But the responses are still there in our bodies and our spirits, and perhaps there are signs that people again want poetry for times when they crave most intensely enlargement of the heart: at weddings and funerals, and in the eerie isolation of lockdown.

So it is perhaps ironic, having talked of the natural rhythms in our bodies, to turn for my first example to T. S. Eliot's "The Waste Land". ${ }^{2}$ One of the most intriguing of Ezra Pound's annotations of Eliot's typescript is where he writes 'too penty' (too close to iambic pentameter) against a line. ${ }^{3}$ At a number of other junctures too Pound seeks to deconstruct the classic rhythms into which he saw Eliot straying. As Marshall McLuhan noted, ${ }^{4}$ Eliot's original, his typescript with Pound's annotations, and the final "Waste Land" are three very different poems. The eventual product of Pound's 'Caesarean Operation' 5 is an extraordinary poem that certainly takes no prisoners in its constant shift of tone and narrative. Though Eliot himself called it 'just a piece of rhythmical grumbling, ${ }^{6}$ its intricately structured disarray is widely acknowledged to echo the disintegration and loss occasioned by the World War. ${ }^{7}$ It refuses the consolations of iambic pentameter; it refuses to be something beautiful and good to look at or inhabit. But for so many, in almost a hundred years, it has fought its way through the bafflement of the interpreter to enlarge the heart.

What I had not seen until asked to write this essay ${ }^{8}$ was that "The Waste Land" can also be seen as a post-pandemic poem. There is little direct evidence for this - Eliot mentions Spanish flu only once during the main outbreak ${ }^{9}$ - but the period of early gestation of "The Waste Land", the year 1918, was marked by the flu epidemic brought back to the UK by returning troops. A quarter of the population may have been affected, and 228,000 people died. The worldwide death toll is thought to have been fifty million. Some who began to feel ill in the morning were dead by late afternoon. Unlike COVID, Spanish flu was at its most pathogenic in young adults. Eliot was thus in the high-risk group and commuted daily into London 


\section{Singing and dancing in the cruellest month}

through the summer of 1918. We know also from his letters that his health and his wife Vivien's were a constant preoccupation. Impossible then that the incidence of influenza did not form an important part of his consciousness at this time. Both Eliots seem to have had the virus in December 1918, during the second wave of the epidemic. He writes after recovering that it still 'left me so very weak afterwards' ${ }^{10}$ and Vivien notes him 'worrying himself about his mind not acting as it used to do. ${ }^{11}$ Since I drafted this essay, my attention has been drawn to Elizabeth Outka's 2019 study Viral Modernism ${ }^{12}$ which makes the same connection between "The Waste Land" and Spanish flu. One does not have to agree with all Outka's readings to accept her overall thesis that the flu epidemic is an influence on "The Waste Land" "hidden in full view"13 and that the poem possesses a kind of 'delirium logic' ${ }^{14}$ attendant on fever and surrounding death.

In our current plight we can feel with a new intensity the lines 'Unreal City,/Under the brown fog of a winter dawn,/A crowd flowed over London Bridge, so many,/I had not thought death had undone so many'. ${ }^{15}$ In her address during the first lockdown the Queen told us the streets were not empty, they were filled with the love and the care that we have for each other. But Eliot sees something different, he sees in the empty streets the profusion of the dead. It's a very important image, as our sensibilities are dulled by statistics, and we start to regard only a few hundred dead in a day as positive news. Eliot's fourth line quotes Book III of the Inferno of his beloved Dante; London is now the lobby area of Hell itself.

"The Waste Land" is first and foremost a poem of loss, from its very first line 'April is the cruellest month', which evokes Tennyson's "In Memoriam". ${ }^{16}$ And a poem of disconnection, with its staccato narrative style that speaks of the shattering of the assumptions that informed the prewar West. At this time of so much loss, when we struggle to stay connected, and even to sustain any sort of shared narrative of what should be happening to us, it is a profound experience to lose ourselves again in the kaleidoscope that is "The Waste Land". And strikingly, astonishingly, at the end of the last section, "What the Thunder Said", ${ }^{17}$ Eliot turns the kaleidoscope faster and faster through nursery rhyme, Purgatorio, poetry, drama and Sanskrit scripture, and we arrive at the astonishing last line 'Shantih Shantih Shantih' - which Eliot himself paraphrased as 'the peace that passeth understanding'. Beyond what the thunder says, in the sound of sheer silence Elijah heard on the mountain, can be discerned a peace 


\section{Singing and dancing in the cruellest month}

that will never let us go. Peace is not argued for, any more than joy is argued for in "The Rite of Spring" or wisdom in Rodin's "Penseur". It emerges out of concentration of effect, the auditory imagination honed to an extraordinary degree. The assumption-shattering, the disconnection, is faced with honesty that is sometimes savage, and yet the heart is enlarged.

It may be argued that "The Waste Land" is by no means a Christian poem in the way that Eliot's later work, from "Journey of the Magi" onwards, so evidently is. But Lyndall Gordon's work has helped us to see just what a deep spiritual searcher the Eliot of this period was. Indeed she writes that he 'had a capacity, rare in his time, to imagine living by visions. ${ }^{18}$ However, Pound's 'surgery' meant that '[b]y the time Eliot produced the final draft of The Waste Land the dream of sainthood had almost wholly disappeared. ${ }^{, 19}$ Eliot, Gordon writes, 'was forced to rewrite his saint's life in more explicit terms in Ash Wednesday and Four Quartets. ${ }^{20}$ But I part company with Gordon over her disappointment that in the climax of the poem, "What the Thunder Said", plainer language of Christian pilgrimage was abandoned, so that "the thunder now rumbles obscure Sanskrit words'. ${ }^{21}$

Behind those three 'thunderous' words, datta, dayadvam, damyata, lie spiritual imperatives with deep Christian associations - datta, give, or surrender the self, with that most profoundly Christic of movements, that of kenosis. Dayadvam - 'not so much human sympathy as a kind of receptivity to intimations and signs' ${ }^{22}$ - he who has eyes to see, let him see, as the Gospels have it, let him bear reality, in Eliot's later phrase in "Burnt Norton" and Murder in the Cathedral. Damyata - control the self, the last of Paul's list of the fruits of the Spirit in Galatians 5, and hence in a sense standing for the whole list. And what a powerful combination that remains for the pilgrim through this COVID time - looking beyond the immediate interests of the self, seeking to read to the full the signs of these strange times, working with the surges of fear, anxiety and stress so that they do not destroy the self in its relationships, but allow it to bear the fruit of love, joy and peace. "The Waste Land" wins through to the promise of the peace that passes understanding, found not in retreat from the kaleidoscope of feelings and sensations but in its centre, which Eliot was later to glimpse as 'the still point of the turning world' ${ }^{23}$

The second poem I have chosen is "Quarantine", by the Irish poet Eavan Boland, who died in April 2020. It is set in the Potato Famine of the 1840 s, and it tells the story of two Irish peasants forced to leave the 
workhouse because one of them has one of the array of infections that went collectively by the name of 'famine fever'. ${ }^{24}$

To me this is a poem of almost unbearable poignancy, and it feels like an offence even to offer any commentary. Again, one could talk about the poet's craft, the way she uses clumped stresses to avoid easy natural rhythm, her incantatory use of repetition. More powerful still is the architecture of the poem, how she draws us close into the narrative, as close as the last heat of the man's flesh, then moves austerely away into the tones of the prophet. Love can be 'proved' in the 'worst' hour of the 'worst' year, in the darkness that is near to death. And again, anguish and despair are not vanquished in the poem, but we are allowed to feel that love has a largeness of heart, even in defeat and death, that can be proved and can endure.

This poem has for us at present an additional ironic quality that fosters at least in me a deep and painful longing. The woman's feet are held against the man's breastbone. 'The last heat of his flesh was his last gift to her.' Touch, the pressure of another's flesh, the warmth of another's blood through skin on skin, is so often denied at present even to the dying. This virus that is costing so much is also depriving us of precious moments of touch, the value of which is incalculable.

There are, too, heavy echoes of the issues of justice that also lurk behind our own present crisis in Boland's phrase 'the toxins of a whole history'. As is often pointed out at present, the toxins of a deeply unequal society sustained on individualism and consumption and inequality are exacerbating the suffering brought by the virus. By an especially bitter twist, the brunt is being borne not only by the most vulnerable in terms of age and previous health, but also by racial minorities, who so often have been the object of prejudice and discrimination.

So "Quarantine" is a poem to sit with in these times, to let its feeling and its prophecy work in hearts so much in need of enlargement.

I offer here one more poem, which stems directly from this strangest of Easters, that of 2020. The priest-poet Malcolm Guite has made a major contribution to Christian poetry recently, especially in his sonnet collection Sounding the Seasons. Guite's ability to work with theological themes, and using the resources of metre and rhyme, are a delight to many. Here is his reflection on this Easter day. 


\section{Easter 2020 25}

And where is Jesus, this strange Easter day?

Not lost in our locked churches, anymore

Than he was sealed in that dark sepulchre.

The locks are loosed; the stone is rolled away,

And he is up and risen, long before,

Alive, at large, and making his strong way

Into the world he gave his life to save,

No need to seek him in his empty grave.

He might have been a wafer in the hands

Of priests this day, or music from the lips

Of red-robed choristers, instead he slips

Away from church, shakes off our linen bands

To don his apron with a nurse: he grips

And lifts a stretcher, soothes with gentle hands

The frail flesh of the dying, gives them hope,

Breathes with the breathless, lends them strength to cope.

On Thursday we applauded, for he came

And served us in a thousand names and faces

Mopping our sickroom floors and catching traces

Of that corona which was death to him:

Good Friday happened in a thousand places

Where Jesus held the helpless, died with them

That they might share his Easter in their need,

Now they are risen with him, risen indeed.

Pentameter resurrected. Guite's prosody is in the lineage of Shakespeare and Herbert, rather than the high modernism of Eliot and Pound. But this is pentameter used with a flexibility and sinuousness that speaks of a poet exploring, bending his mind around material that is so weighty that (to revert for a moment to Eliot) 'Words strain/Crack and sometimes break, under the burden,/ [...] Will not stay still. ${ }^{, 26}$

Guite's poem is not poetic thought that has condensed into the formal rigour of the sonnet. Its texture is open, its thought will not stay still, rather 


\section{Singing and dancing in the cruellest month}

its movement takes us on and on into the intensity of Jesus' solidarity with the beleaguered and dying, and then into a simple resolving couplet.

The last line, I think, shows Guite's great skill with tone and cadence. The acclamation 'Christ is risen, he is risen indeed, alleluia!' is the Church's proclamation at its most triumphal. It is a shout of the new age dawning. And as a number of theologians of trauma have remarked, the univocal proclamation of victory and triumph, of the old as passed away and the wineskins full of the wine of heaven, that proclamation sits awkwardly, sometimes unbearably, with the experience of the traumatised, and those who are for whatever reason immured in their suffering. ${ }^{27}$ Guite's last line is sure of the resurrection and the life, but there is no alleluia to it. The rhyme of Guite's couplet tells us that God has met the need of the helpless and the dying, but the cadence tells us that this meeting is a muted one. It is enough. But it does not shout, as so much Christian worship has done in the past, in the faces of those who grieve unbearable loss.

Still the completeness of the sentiment, the assurance of the last line, will bother some. For some even this delicate exploration will seem too certain of itself. I think, however, that this poem functions somewhat like those psalms of lament that end in confession of praise. The ancient Israelite hymn-writers knew the grieving of the heart, and its enlargement, and that sometimes to sing out what we cannot yet feel can be part of our healing, part of staying in register with the cosmic song of the evermysterious God. We can rehearse those psalmic endings, as we can Guite's concluding couplet, and their poetry can help us feel that anguish and despair, frustration and anger and fear of the future, are all held within a larger story.

There is an argument that having chosen to write about poetry in the context of theology and the COVID crisis, I should merely have devoted the entire essay to the lament psalms in the Hebrew Bible. To live with the Psalter, with its honesty at anguish and despair and anger and frustration and praise and joy and pain and sadness, is itself to be offered resources for resilience of heart that are all too sorely needed at this time. As it happens I have also been living, first, with Dietrich Bonhoeffer's prison poems, and more recently with Barrows and Macy's remarkable translation of Rilke's Book of Hours. We may be beset by furious overactivity at this strange time, but there is the opportunity also to go deeper into the interior life, or rather to let that life be itself, and allow its resources 


\section{Singing and dancing in the cruellest month}

to change us. Rilke writes, 'When gold is in the mountains/and we've ravaged the depths/till we've given up digging,/it will be brought forth into day/by the river that mines/the silences of stone. ${ }^{28}$

One last thought before I end. In my most recent book, Theology in a Suffering World, I try to persuade the reader that the natural world as created by God is a deeply ambiguous place. It shows us the amazingly intricate life strategies that have evolved over billions of years - the sprint of the cheetah, the stoop of the peregrine falcon, and, yes, the ingenious strategies of pathogens. Too many commentators, in the barnstorm of blogs and opinion pieces and self-help streams that has characterised the pandemic, have wanted to slide over God's ultimate responsibility for this sort of world. A more honest theology, one truer to the Psalms and those reframers of Israelite faith in the disaster of the exile, recognises that, ultimately, God is the maker of weal and woe alike in the natural world, ${ }^{29}$ though of course our own hubris and folly have a huge part to play in our suffering. We can long for God and sing God's songs, but we should do so recognising the ambiguous character of God's creation.

Grasping that God's world is not only the world of lovely PowerPoints of sunsets over mountains and oceans but also of predation and parasitism, of plagues and viruses, is like the shift in aesthetic required to appreciate Stravinsky's Rite of Spring in Nijinsky's revolutionary choreography, after being schooled in the appreciation of classical ballet. The dancers had to be taught to dance on their heels instead of their points. To ground our contemplation of the natural world on a real appreciation of the ambiguous character of that world is to be forced back on our heels by the weight of its reality, but therefore to dance in a more grounded way. ${ }^{30}$

It is always, then, the calling of those who would learn from the natural world to learn to dance on our heels. 2020 brought what seemed like the cruellest of springs. Faced with all the loss and frustration of the time, it is also part of the calling of human beings to sing the songs the poets offer us, and thereby enlarge hearts that have grown all too familiar with pain and sadness and despair. 
Singing and dancing in the cruellest month

Notes

1 Rita Nakashima Brock and Rebecca Ann Parker, Proverbs of Ashes: Violence, Redemptive Suffering, and the Search for What Saves Us (Boston: Beacon Press, 2001), 115.

2 The text of the poem can be found at poetryfoundation.org.

3 T. S. Eliot, The Waste Land: A Facsimile and Transcript of the Original Drafts Including the Annotations of Ezra Pound, ed. Valerie Eliot (London: Faber \& Faber, 1971), 11.

4 Marshall McLuhan, "Pound, Eliot, and the Rhetoric of The Waste Land", New Literary History 10 (1979): 557-80.

5 Quoted in McLuhan, "Pound", 566.

6 Facsimile and Transcript, no page number.

7 Eliot wrote in his essay on "In Memoriam" that "It happens now and then that a poet by some strange accident expresses the mood of his generation'. T. S. Eliot, Selected Essays, $3^{\text {rd }}$ edn. (London: Faber \& Faber, 1951), 334.

8 The invitation came from the Faculty of Divinity of the University of Edinburgh as part of their TheoCon series.

9 Writing to his mother on 7 July 1918, Valerie Eliot, ed., The Letters of T. S. Eliot, Volume 1: 1898-1922 (London: Faber \& Faber, 1988), 237.

10 Letter to his mother, 8 December 1918, Letters Vol. 1, 259.

11 Vivien Eliot to TSE's mother, 15 December 1918, Letters Vol. 1, 261.

12 Elizabeth Outka, Viral Modernism: The Influenza Pandemic and Interwar Literature (New York: Columbia University Press, 2019), especially Chapter 5.

13 Ibid., 151.

14 Ibid., 145.

15 "The Waste Land" lines 60-3, Facsimile and Transcript, 136.

16 Craig Raine, T. S. Eliot (New York: Oxford University Press, 2006), 75.

17 A. David Moody claims that 'the drafts of The Waste Land show that what [Eliot] was really wanting to write was "What the Thunder Said". Thomas Stearns Eliot: Poet (Cambridge: Cambridge University Press, 1994), 54

18 Lyndall Gordon, Eliot's Early Years (Oxford: Oxford University Press, 1977), 90.

19 Ibid., 95. 
20 Ibid., 119.

21 Ibid., 113.

22 Ibid., 114.

23 T. S. Eliot, "Burnt Norton" in The Poems of T. S. Eliot, Vol. 1: Collected and Uncollected Poems, ed. Christopher Ricks and Jim McCue (London: Faber \& Faber, 2015), 181.

24 The text of the poem can be found at https://apoemforireland.rte.ie/ shortlist/quarantine/. It is published in Eavan Boland, New Collected Poems (Manchester: Carcanet, 2005), 178.

25 From an unpublished collection and reproduced with the permission of the author.

26 Eliot, "Burnt Norton", Poems, Vol. 1, $183 \mathrm{f}$.

27 See for example Shelly Rambo, Spirit and Trauma: A Theology of Remaining (Louisville, Ky.: Westminster John Knox Press, 2010).

28 Rainer Maria Rilke, Rilke's Book of Hours: Love Poems to God, trans. Anita Barrows and Joanna Macy (New York: Riverhead Books, 2005), 75.

29 See e.g. Isaiah 45:7.

30 Christopher Southgate, Theology in a Suffering World: Glory and Longing (Cambridge: Cambridge University Press, 2018), 147. 